\title{
The bacteriophage 434 operator/repressor system in yeast
}

\author{
Carl I. Webster † and William J. Brammar \\ Author for correspondence: William J. Brammar. Tel: +44 1162523442 . Fax: +44 1162523369.
}

$\mathrm{ICI} /$ University Joint

Laboratory, Department of Biochemistry, University of Leicester, University Road, Leicester, LE1 7RH, UK

\begin{abstract}
The ability of the bacteriophage 434 operator/repressor system to function in a eukaryotic cell has been explored. An idealized 434 operator was placed at various positions in the PGK promoter of Saccharomyces cerevisiae: within the upstream activator sequence, close to the TATA box, and downstream of the transcription-initiation site. Expression of the $434 \mathrm{cl}$ gene from a $2 \mu \mathrm{m}$-based plasmid resulted in significant repression of gene expression from constructs containing the altered promoters linked to a $\beta$-galactosidase reporter gene. Attempts to use a variant of the 434 repressor that has the binding specificity of the P22 repressor (434 $4^{\text {P22 }}$ ) were unsuccessful, due to a severely inhibitory effect of this gene-product on the growth of the yeast cells.
\end{abstract}

Keywords: bacteriophage 434 operator/repressor, P22 repressor, Saccharomyces cerevisiae, regulation of gene expression

\section{INTRODUCTION}

Repressor proteins effect the negative control of gene expression by binding to their cognate operator sequences with high affinity, thereby preventing access of RNA polymerase to the promoter. For the best-studied examples of repressors derived from bacteria and bacteriophages high-resolution structures of repressor-operator complexes are available.

Several repressors that normally function in prokaryotic cells have been used to repress expression from suitably modified promoters in a number of different eukaryotic cells. In mouse cells expressing the Escherichia coli lex $A$ repressor gene the insertion of lex $A$ operators into the thymidine kinase promoter resulted in repression of a chloramphenicol acetyltransferase reporter gene by up to 10-fold (Smith et al., 1988). The lac operator/repressor system has been shown to function in both mammalian and plant cells. $\mathrm{Hu} \&$ Davidson (1987) showed that in mouse cells the insertion of a lac operator between the initiation codon and the transcription-start site, between the transcription-start point and the TATA box, or upstream of the TATA box, could block transcription in the presence of the lac repressor and that this block was relieved in the presence of the inducer IPTG. Similar findings have also been reported by Brown et al. (1987) and Figge et al. (1988). The lac repressor has further been

†Present address: Department of Plant Sciences, University of Cambridge, Downing Street, Cambridge, CB2 3EA, UK.

Abbreviation: UAS, upstream activator sequence. shown to repress expression when the operator is located some distance downstream of the transcription-initiation site (Deuschle et al., 1990), thus demonstrating that a bacterial repressor can be an effective block to transcriptional elongation by RNA polymerase II. Wilde et al. (1992) demonstrated that the lac operator/repressor system functioned in tobacco cells, where expression of both stably transformed and transient reporter constructs were efficiently repressed, and that this repression could be relieved by IPTG. The tet repressor is also able to mediate efficient repression of expression from a plant promoter, the effect being relieved by tetracycline (Gatz \& Quail, 1988; Gatz et al., 1991).

In yeast, RNA polymerase II-directed transcription has been repressed by the $E$. coli lex $A$ repressor when lex $A$ operators have been inserted into the GAL1 promoter between the upstream activator sequence (UAS) and the TATA box (Brent \& Ptashne, 1984). Also in yeast, the tet repressor has been shown to block RNA polymerase IIIdependent transcription when operators were inserted near to the transcription-start site of a tRNA gene (Dingermann et al., 1992).

The bacteriophage 434 operator/repressor system has been extensively characterized both in vivo and in vitro, but its ability to function in eukaryotic cells has not previously been investigated. In common with many other bacterial DNA-binding proteins, the 434 repressor utilizes the helix-turn-helix motif for DNA recognition (Pabo \& Sauer, 1984). X-ray crystallographic analyses have shown that the third $\alpha$-helix within the N-terminal DNA-binding domain of the protein makes contact with the operator DNA in the major groove (Anderson et al., 1985), with 
sequence-specific contacts being made by three glutamine residues within this $\alpha$-helix, at positions 28,29 and 33 of the protein (Anderson et al., 1987; Aggarwal et al., 1988). The DNA-binding specificity of the $434 c I$ gene product has been altered both by a single amino acid change, complementing single base-pair changes in the operator (Wharton \& Ptashne, 1987), and by more substantial alterations to the $\alpha$-helix (Wharton et al., 1984; Wharton $\&$ Ptashne, 1985). By substituting just five amino acids in the $\alpha-3$ helix of the $434 c I$ gene-product by the amino acids in the corresponding positions in the DNA-binding helix of the P22 repressor, a hybrid 434 repressor $\left(434^{\mathrm{P} 22}\right)$ was created which retained all the properties of the 434 repressor except for the DNA-binding specificity, which was switched to that of the P22 repressor (Wharton \& Ptashne, 1985). Hollis et al. (1988) subsequently demonstrated that by combining purified 434 and $434^{\text {P22 }}$ repressor proteins in vitro, a footprint could be produced on hybrid operator DNA consisting of half-sites from each of the 434 and the P22 operators, indicating the in vitro formation of a heterodimeric repressor of hybrid specificity. Recently it has been demonstrated that this heterodimeric 434 repressor is able to repress gene expression in E. coli at a level similar to those achieved with either homodimer (Webster et al., 1992).

We wish to be able to control gene expression in eukaryotes by the binding of a repressor to an operator sequence within the promoter of a target gene. In order to be able to do this without prior manipulation of the promoter sequence, the 434 repressor was seen as advantageous because of the existence of well-understood variants of this repressor with altered DNA-binding specificities (Wharton \& Ptashne, 1985, 1987), and the established efficacy of the heterodimeric repressor (Webster et al., 1992). In addition, we have developed a genetic selection system that allows selection of altered specificity repressors from a mini-library of 434 repressor genes containing randomized codons for the amino acids that confer DNA-binding specificity (R. J. Wilde and others, unpublished).

To determine whether the 434 repressor is able to function efficiently in the environment of a eukaryotic nucleus, initial repression studies have been undertaken in Saccharomyces cerevisiae. Although 434 operators normally occur in tandem in the phage immunity region, where co-operative interactions between adjacently bound repressor-dimers increase the degree of repression, in this study single operators were used to assess the efficiency of the simple operator-repressor interaction. The results demonstrate that the $434 c I$ gene-product is able to function in $S$. cerevisiae by repression of gene expression from a $P G K$ promoter-lac $Z$ reporter gene containing introduced 434 operators within the $P G K$ promoter. The ability of the $434^{\mathrm{P} 22}$ repressor to function in yeast was also investigated, but its expression in $S$. cerevisiae severely inhibited the growth of the host cells. This observation suggests the caution that heterologous repressor proteins may bind to sequences within a eukaryotic genome and have a major influence on the continued growth of the host cell.

\section{METHODS}

Strains. Saccharomyces cerevisiae: $\mathrm{S} 150-2 \mathrm{~B} ; M A T \mathbf{a}$ ura3-52 trp1289 bis3-D1 leu2-3 leu2-112 $2 \mu \mathrm{m}^{+}$.

E. coli: DH5 $\alpha$ (Hanahan, 1983); $\mathrm{F}^{-}$end $A 1$ bsd $\left(\mathrm{r}_{\mathrm{k}}^{-} \mathrm{m}_{\mathrm{k}}^{+}\right)$supE44 thi$1 \lambda^{-} \operatorname{rec} A 1$ gyr $A 96 \operatorname{rel} A 1 \Delta(\operatorname{argF}-$ lac $Z Y A) \mathrm{U} 169 \phi 80 \mathrm{~d} l a c Z \Delta \mathrm{M} 15$. $\mathrm{X} 11$-blue (Bullock et al., 1987); supE44 bsdR $17 \mathrm{rec} A 1$ end $A 1$ gyrA46 thi rel A1 lac $\mathrm{F}^{\prime}\left[\right.$ pro $A B^{+}$lac ${ }^{q}$ lacZAM15 Tn10]. RZ1032 (Künkel et al., 1987); HfrKL16 PO/45 [lys A(61-62)] dut-1 ung1 thi-1 relA1 supE44 zbd-279:: Tn10.

Standard molecular biology techniques. All general molecular biological techniques were carried out according to Sambrook et al. (1989). All plasmids were maintained in E. coli $\mathrm{DH} 5 \alpha$ unless otherwise stated.

Site-directed mutagenesis. This was carried out by a variation of the method of Künkel et al. (1987). An overnight culture of E. coli RZ1032 was inoculated with M13mp19 phage containing the DNA to be mutated inserted in the polylinker and the culture was left at room temperature for $30 \mathrm{~min}$. This was diluted 100-fold into $2 \times$ YT ( $\mathrm{g} \mathrm{l}^{-1}$ : Bacto-tryptone 16, Bacto yeast extract $10, \mathrm{NaCl} 5$ ) with $7 \cdot 5 \mu \mathrm{g}$ tetracycline $\mathrm{ml}^{-1}$ and grown for $6 \mathrm{~h}$ at $37^{\circ} \mathrm{C}$ with vigorous agitation. The cells were removed by centrifugation at $8000 \mathrm{~g}$ for $20 \mathrm{~min}$ and the phage precipitated from the supernatant by the addition of $\mathrm{NaCl}$ and polyethylene glycol (PEG) 6000 to $30 \mathrm{mg} \mathrm{ml}^{-1}$ and $40 \mathrm{mg} \mathrm{ml}^{-1}$ respectively. The phage particles, collected by centrifugation at $8000 \mathrm{~g}$ for $20 \mathrm{~min}$, were resuspended in $10 \mathrm{ml} \mathrm{TE}(10 \mathrm{mM}$ Tris/ $\mathrm{HCl}, 0 \cdot 1 \mathrm{mM}$ EDTA; $\mathrm{pH} 8 \cdot 0$ ) by vigorous vortexing. The protein coats were removed by phenol extraction and the DNA precipitated by ethanol precipitation and resuspended in $0.5 \mathrm{ml}$ sterile deionized water. This DNA contains $U$ in place of $T$ residues at a small number of positions, making it unstable in strains of E. coli that do not carry the ung mutation.

Approximately $1 \mathrm{pmol}$ of the template and $10 \mathrm{pmol}$ of $5^{\prime}$ phosphorylated mutagenic oligonucleotide were annealed in $20 \mu \mathrm{l}$ sterile, deionized water containing $1 \cdot 2 \mu \mathrm{l} 20 \times \mathrm{SSC}$. The synthesis of the complementary strand, primed from the mutagenic oligonucleotide, was carried out in a $100 \mu \mathrm{l}$ reaction containing $500 \mu \mathrm{M}$ of each dNTP, $1 \mathrm{mM} \mathrm{ATP}, 10 \mathrm{mM} \mathrm{MgCl}_{2}$, $100 \mathrm{mM}$ Tris $\mathrm{pH} 7.5,2 \mathrm{mM}$ DTT, 20 units of T4 DNA polymerase and 20 units of $\mathrm{T} 4$ ligase. The reaction mixture was incubated on ice for $5 \mathrm{~min}$, at room temperature for $5 \mathrm{~min}$ and at $37^{\circ} \mathrm{C}$ for $2 \mathrm{~h}$, after which the reaction was terminated by the addition of $5 \mu \mathrm{l} 500 \mathrm{mM}$ EDTA, pH 8.0. An aliquot of this reaction was used to transform $E$. coli strain XL1-blue and mutated phages were identified by restriction enzyme digestion of the RF DNA or sequencing of the single-stranded phage DNA.

Construction of reporter plasmids. The $P G K$ promoter and terminator were cut from pCH137 (Hadfield et al., 1990) on a HindIII fragment and cloned into the HindIII site in the polylinker of M13mp19. Site-directed mutagenesis (Künkel et al., 1987) was used to introduce a $S \mathrm{mal}$ site at position -605 , relative to the RNA initiation point, in the $P G K$ promoter. Further site-directed mutagenesis was used to create unique restriction sites at various positions in the $P G K$ promoter. The six different $P G K$ promoter-terminator constructs were removed from M13 RF DNA as $1 \mathrm{~kb}$ SmaI-HindIII fragments and ligated into the polylinker of a variant of pUC19, pUC19EN, which contains a NarI site in place of the EcoRI site in the polylinker region, to give the plasmids in Table 1 . The plasmids pYCW3, pYCW5 and pYCW6 were opened at the unique, introduced restriction sites and 434 operators inserted as annealed oligonucleotides, to give the plasmids pYCW8, pYCW10 and pYCW11 respectively. Plasmid pYCW4 was cut with EcoRV and $X b o I$ and annealed oligonucleotides used to 


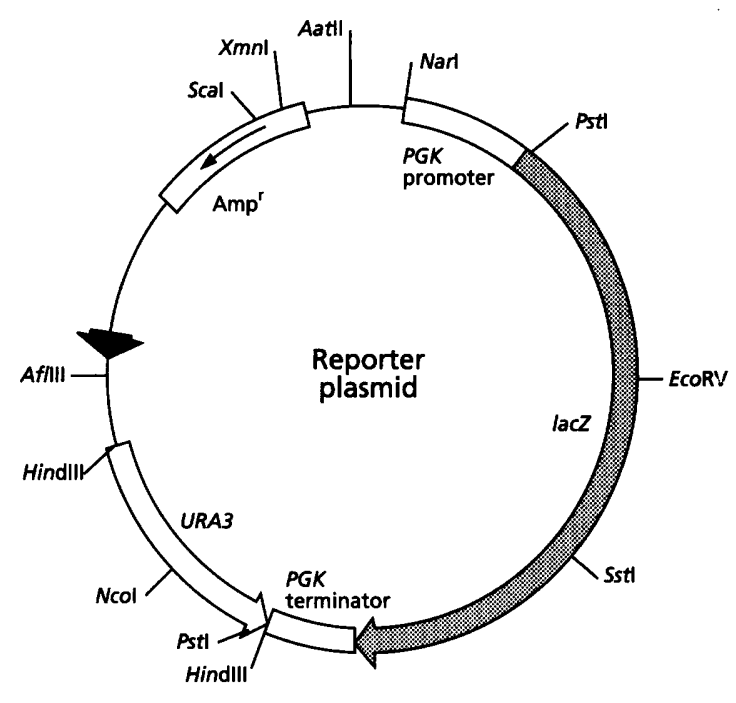

Fig. 1. The basic reporter plasmid. The reporter plasmid contains the origin of replication and the ampicillin-resistance gene from pUC19 for maintenance in E. coli, the URA3 gene for homologous recombination and prototrophic selection in $S$. cerevisiae and the $\beta$-galactosidase gene from $E$. coli under the control of the yeast PGK promoter and terminator. The promoter in the constructs pYCW37-41 contain 434 operators within the PGK promoter region. The location of these operators does not affect the levels of expression of $\beta$ galactosidase in yeast in the absence of repressor.

replace the DNA between the two sites, retaining existing sequences bound by yeast transcription factors but also introducing a 434 operator, to give plasmid pYCW9. Plasmid pYCW7 was cut with $B g / \mathrm{II}$ and $S t u \mathrm{I}$ and annealed oligonucleotides used to replace DNA between the two sites with original sequence containing a 14 bp replacement downstream of the mRNA initiation point to introduce the 434 operator, to give plasmid $\mathrm{pYCW} 12$.

Part of the lac $Z$ gene was cut from pAH193-41A (van Gorcom et al., 1986) on a HindIII-EcoRI fragment and cloned between the HindIII and EcoRI sites in pBR328 (Soberon et al., 1980). This plasmid was cut with HindIII and SalI and the first 11 codons of the lac $Z$ gene introduced by ligation of annealed complementary oligonucleotides containing a Bam HI site $5^{\prime}$ of the initiation codon, to give the plasmid pCW7. Neither the $S a l$ nor the HindIII site was retained in the ligation.

The plasmid pYCWPGK was cut at the unique HindIII site $3^{\prime}$ of the $P G K$ terminator and a HindIII fragment containing the $U R A 3$ gene from YIp30 inserted to give pYCW19. The last 17 codons of the lac $Z$ gene were synthesized as complementary oligonucleotides with an EcoRI-compatible overhang at the $5^{\prime}$ end and a BglII-compatible overhang at the $3^{\prime}$ end. This fragment was ligated between the EcoRI and $B g / I I$ sites in pYCW19 and the product checked by sequencing. This plasmid was opened at the NarI and EcoRI sites and the fragment containing the remainder of the lac $Z$ gene, isolated from $\mathrm{pCW} 7$ on an EcoRI-NarI fragment, introduced by ligation. The resulting plasmid, $\mathrm{pCW} 31$, was cut at the unique $\mathrm{Bam} \mathrm{HI}$ site immediately $5^{\prime}$ of the start codon of the lac $Z$ gene and at the unique NarI site further upstream of the lac $Z$ gene. The series of $P G K$ promoters containing operators, isolated on $B g / \mathrm{II}-\mathrm{NarI}$ fragments from pYCWPGK, 8, 9, 10,11 and 12, could then be ligated in to form a series of reporter constructs (Fig. 1). These

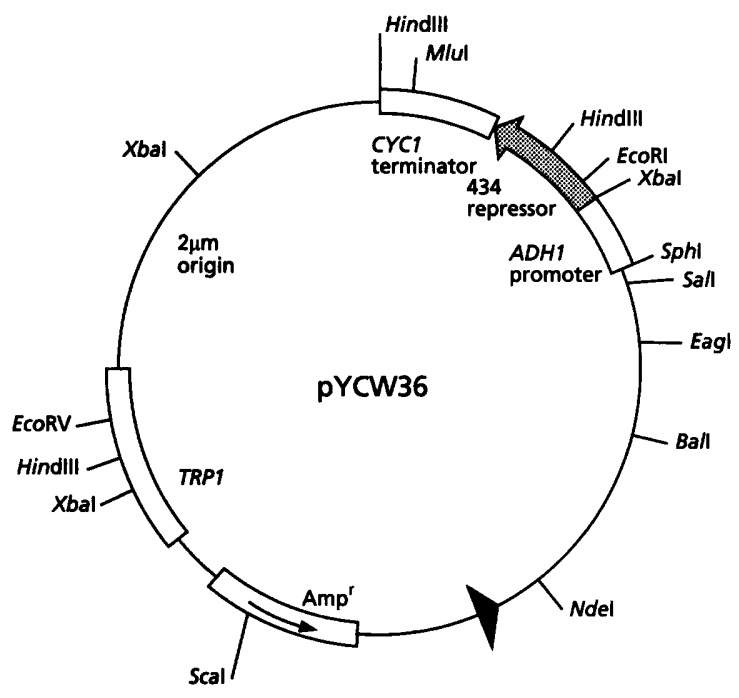

Fig. 2. Plasmid designed to express the 434 repressor. The plasmid pYCW36 is based on pYCDE-2 (Hadfield et al., 1986). It contains an origin of replication and the ampicillin-resistance gene for maintenance and selection in $E$. coli, and the $2 \mu \mathrm{m}$ origin and the TRP1 gene for maintenance and selection in yeast. The $\mathbf{4 3 4}$ gene is under the control of a truncated version of the $A D H 1$ promoter which confers constitutive expression (Beier \& Young, 1982) plus the CYC1 terminator.

could be linearized at the unique $N c o$ I restriction site within the $U R A 3$ gene to aid homologous recombination into the ura 3 locus of the $S$. cerevisiae host.

Construction of a plasmid expressing the 434 repressor. The $2 \mu \mathrm{m}$ origin and most of the TRP1 gene were removed from pYcDE-2 (Hadfield et al., 1986) by digestion with $X b a \mathrm{I}$ and HindIII, followed by religating the remainder of the plasmid with annealed oligonucleotides used to create a small linker joining the $X b a I$ and HindIII ends. The $X b a I$ site was destroyed in the ligation and an XboI site introduced. The resulting plasmid, pcDE1, was opened at the unique EcoRI cloning site between the $A D H 1$ promoter and the $C Y C 1$ terminator, and a small linker inserted to introduce unique $\mathrm{Xba \textrm {I }}$ and $\mathrm{Bam} \mathrm{HI}$ sites to give the plasmid pACXB1. The EcoRI site was not retained in the ligation. The $434 c I$ gene was cut from pPLRT1 (Webster et al., 1992) on an XbaI-Sau3AI fragment and ligated into pACXB1 opened at its $X b a I$ and BamHI sites to give pYCW34. Both pYCW34 and pYcDE-2 were cut with $S a l I$ and $M l u I$ and the 434 expression cassette ligated into the $2 \mu \mathrm{m}$ plasmid to give pYCW36 (Fig. 2).

Construction of plasmids expressing the $434^{\text {P22 }}$ repressor. This construction was similar to the one described above except that the $434^{\mathrm{P22}}$ gene was substituted for the wild-type 434 gene. This involved isolating the $434^{\mathrm{P22}}$ coding region from pPLRT2 (Webster et al., 1992) on a XbaI-Sau3AI fragment and substituting it for the XbaI-Sau3AI fragment containing the wildtype $434 c I$ gene to give pYCW28 (Fig. 3a).

A second expression vector was also constructed for the $434^{\mathbf{P 2} 2}$ repressor. This was designed to integrate into the yeast genome maintaining single copy number. The promoterrepressor-terminator cassette made by ligating the $X b a \mathrm{I}-S a$ u $3 \mathrm{AI}$ fragment containing the $434^{\mathrm{P22}}$ repressor coding region into pACXB1 was removed on a $S a l I-X b o I$ fragment and cloned into the unique $S a l$ site in pYRG12 (Hadfield et al., 1987). Two 

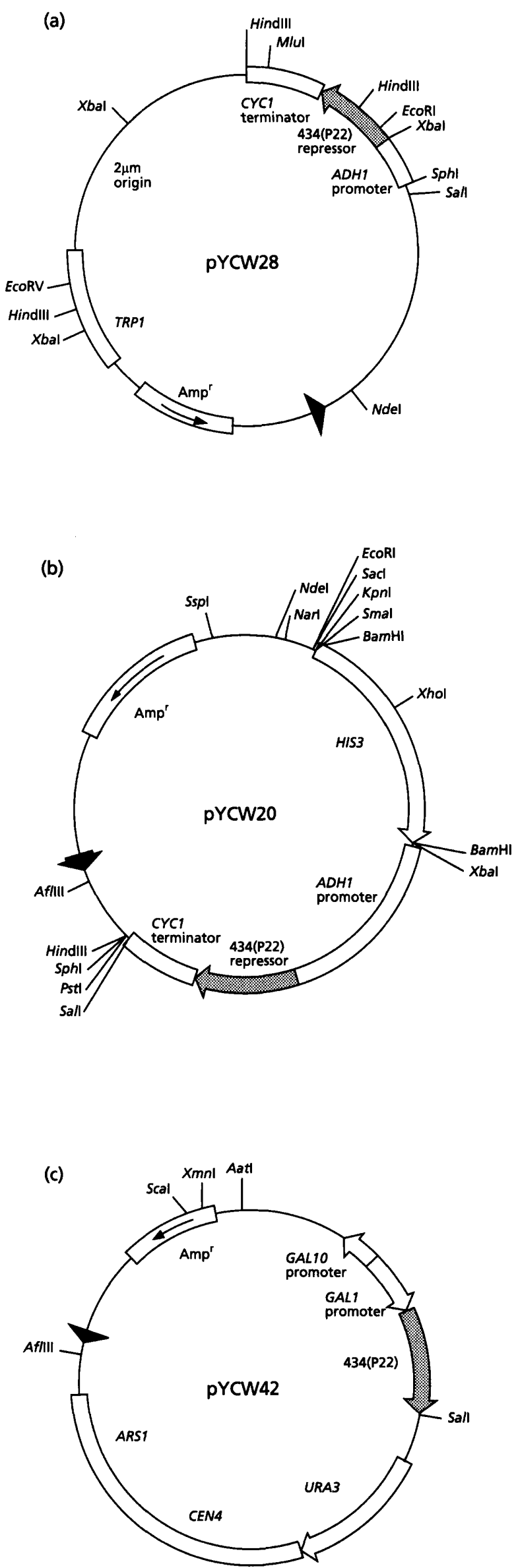

clones were picked, each having the repressor cassette but in different orientations: these were pYCW20A and B (Fig. 3b). These plasmids should express the $434^{\mathrm{P22}}$ repressor constitutively from a truncated version of the $A D H 1$ promoter and carry the HIS 3 gene. Linearization of the plasmid with $X b o \mathrm{I}$, which cuts uniquely within the HIS3 gene, improves the frequency of homologous recombination into the HIS 3 locus.

A third plasmid to express the $434^{\mathrm{P22}}$ repressor was also designed, based on the centromere plasmid pBM150 (Johnston $\&$ Davis, 1984). The $434^{\mathrm{P} 22}$ repressor gene was cut from pPLRT2 on an XbaI-Sau3AI fragment and cloned into the polylinker of pIC19H (Marsh et al., 1984) opened at its BamHI and $\mathrm{XbaI}$ sites, to give $\mathrm{PCW} 37 \mathrm{~B}$. This plasmid was then cut with $B g I I$ and $S a l I$ and the $434^{\mathrm{P22}}$ repressor gene cloned into pBM150 opened at its Sall and Bam HI sites to give the plasmid pYCW42 (Fig. 3c). This places the $434^{\mathrm{P} 22}$ repressor gene under the control of the yeast $G A L 1$ promoter. During growth on glucose-based media the repressor gene should be silent, whereas during growth on galactose in the absence of glucose it should be expressed.

DNA sequencing. Both single-stranded M13 phage DNA and double-stranded plasmid DNA were sequenced by the dideoxytermination method of Sanger et al. (1974), using a Pharmacia T7 sequencing kit according to the manufacturer's instructions.

Transformation of yeast. An overnight culture of $S$. cerevisiae

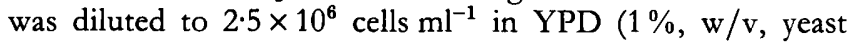
extract, $2 \%, \mathrm{w} / \mathrm{v}$, peptone and $2 \%, \mathrm{w} / \mathrm{v}$, glucose) and grown to $10^{7}$ cells $\mathrm{ml}^{-1}$. The cells were collected by centrifugation, washed in TE $(\mathrm{pH} 7.5)$ several times and resuspended in 1/10 the original culture volume in lithium acetate solution $(0.1 \mathrm{M}$ lithium acetate in $\mathrm{TE}, \mathrm{pH} 7 \cdot 5)$. These suspensions were incubated at $30^{\circ} \mathrm{C}$ for $1 \mathrm{~h}$ with light agitation and divided into $300 \mu \mathrm{l}$ aliquots. DNA was added to the $300 \mu \mathrm{l}$ aliquots at $1 \mu \mathrm{g}$ for closed circular plasmids and $10 \mu \mathrm{g}$ for linearized plasmids. Then $700 \mu \mathrm{l}$ of a $50 \%(\mathrm{w} / \mathrm{v})$ solution of PEG 4000 in sterile deionized water was added and incubated at $30^{\circ} \mathrm{C}$ for $30 \mathrm{~min}$ without agitation. The cells were heat-shocked at $42^{\circ} \mathrm{C}$ for $5 \mathrm{~min}$ and plated onto selective media. Transformants appeared as individual colonies after $3-7 \mathrm{~d}$ at $30^{\circ} \mathrm{C}$.

Assay of $\boldsymbol{\beta}$-galactosidase activity. The assay method used was a variation of the procedure of Miller (1972). The strains to be

Fig. 3. Plasmids designed to express the $434^{\mathrm{P} 22}$ repressor. (a) The plasmid pYCW28 is identical to pYCW36 (Fig. 2) except that it is designed to express the $434^{\text {P22 }}$ repressor. (b) The plasmid pYCW20 is designed to express the $434^{\mathrm{P22}}$ repressor from the same expression system as pYCW28 and pYCW36, except that it does not contain the $2 \mu \mathrm{m}$ origin of replication and cannot be maintained in the yeast nucleus without integration into the host genome. This is achieved by linearization of the plasmid within the HIS3 locus at the unique Xhol site, which increases the frequency of homologous recombination up to 1000-fold (Orr-Weaver et al., 1981). (c) The plasmid pYCW42 is based on the plasmid pBM150 (Johnston \& Davis, 1984) and is designed for the inducible expression of $434^{\mathrm{P} 22}$ from the GAL1 promoter. The plasmid contains the origin of replication and ampicillinresistance gene for maintenance and selection in $E$. coli, the ARS1 and CEN4 elements for autonomous replication in yeast and the URA3 gene for prototrophic selection. The $434^{\mathrm{P22}}$ repressor gene is under the control of the GAL1 promoter: during growth on a glucose-based media the GAL1 promoter is silent whereas during growth on galactose-based media the GAL1 promoter drives expression of the $434^{\mathrm{P} 22}$ gene. 
assayed were grown overnight in quadruplicate in semi-defined minimal selective medium $(6.7 \%, \mathrm{w} / \mathrm{v}$, Yeast Nitrogen Base without amino acids, $2 \%$, w/v, glucose, $40 \mu \mathrm{g}$ leucine $\mathrm{ml}^{-1}$, $40 \mu \mathrm{g}$ histidine $\mathrm{ml}^{-1}$ ) at $30^{\circ} \mathrm{C}$ with vigorous shaking. The $\mathrm{OD}_{600}$ of each culture was determined immediately prior to determining the $\beta$-galactosidase activity. A sample of $440 \mu \mathrm{l}$ was taken and mixed with $110 \mu \mathrm{l} 5 \times \mathrm{Z}$ buffer $(1 \times \mathrm{Z}$ buffer is $60 \mathrm{mM}$ $\mathrm{Na}_{2} \mathrm{HPO}_{4}, 40 \mathrm{mM} \mathrm{NaH} \mathrm{PO}_{4}, 10 \mathrm{mM} \mathrm{KCl}, 1 \mathrm{mM} \mathrm{MgSO}$, $50 \mathrm{mM} \quad \beta$-mercaptoethanol, adjusted to $\mathrm{pH} 7.0$ and filtersterilized); a $10 \mu \mathrm{l}$ sample of this was diluted $1 / 10$ in $1 \times \mathrm{Z}$ buffer. To each sample was added $5 \mu \mathrm{l} 0 \cdot 1 \%$ SDS and $25 \mu \mathrm{l}$ chloroform followed by vortexing for $10 \mathrm{~s}$. To start the reaction $90 \mu \mathrm{l}$ of $4 \mathrm{mg}$ ONPG ml $\mathrm{m}^{-1}$ was added; the samples were incubated at $30{ }^{\circ} \mathrm{C}$ for $30 \mathrm{~min}$ then the reaction stopped by the addition of $250 \mu \mathrm{l} 1 \mathrm{M} \mathrm{Na}_{2} \mathrm{CO}_{3}$. Cells were cleared from the solution by a $30 \mathrm{~s}$ spin in a microfuge at full speed and the $A_{\mathbf{4 2 0}}$ determined. Results were treated as follows: the $A_{420}$ was corrected for dilutions, multiplied by 1000 and divided by 30 (min) and the $\mathrm{OD}_{600}$ of the culture; this gives the results in $\beta$ galactosidase units $\mathrm{min}^{-1}$ per $\mathrm{OD}_{600}$ unit. Data from control and repressed cultures were statistically treated using Student's $t$ test to check the hypothesis that they were different data-sets to greater than $95 \%$ certainty.

\section{RESULTS AND DISCUSSION}

\section{Experimental approach}

In order to measure the repression achieved by the 434 repressor in yeast, strains carrying the reporter plasmids were transformed with pYCW36 expressing the 434 repressor, and with $\mathrm{pYcDE}-2$ as a negative control. The difference in the levels of $\beta$-galactosidase expression from the reporter gene between the two strains would then give the level of repression. A control was also included which measured the repression of the reporter construct when no artificially introduced operators were present.

\section{Analysis of $434 \mathrm{cl}$ expression in yeast}

The yield of the 434 repressor in strains carrying the plasmid pYCW36 was determined by Western analysis, using a polyclonal antiserum against the 434 repressor. The results (not shown) demonstrated that the 434 repressor was expressed at $0 \cdot 25-0.5 \%$ of cell protein. This is less than the $1-2 \%$ of cellular protein produced by expressing the E. coli chloramphenicol acetyltransferase gene from a similar plasmid (Hadfield et al., 1987). The reasons for this difference in yield of the two geneproducts are unclear.

\section{Location of operators in the PGK promoter}

For studies of repression of gene expression in yeast by the 434 operator/repressor system the $P G K$ promoter of S. cerevisiae was chosen. This choice was based on the promoter's ability to direct high-level expression of foreign genes in S. cerevisiae (Derynck et al., 1983), facilitating detection of the reporter gene-product even at repressed levels. In addition, much useful information is available about the location of regions within the $P G K$ promoter responsible for the high levels of transcription associated with this gene.

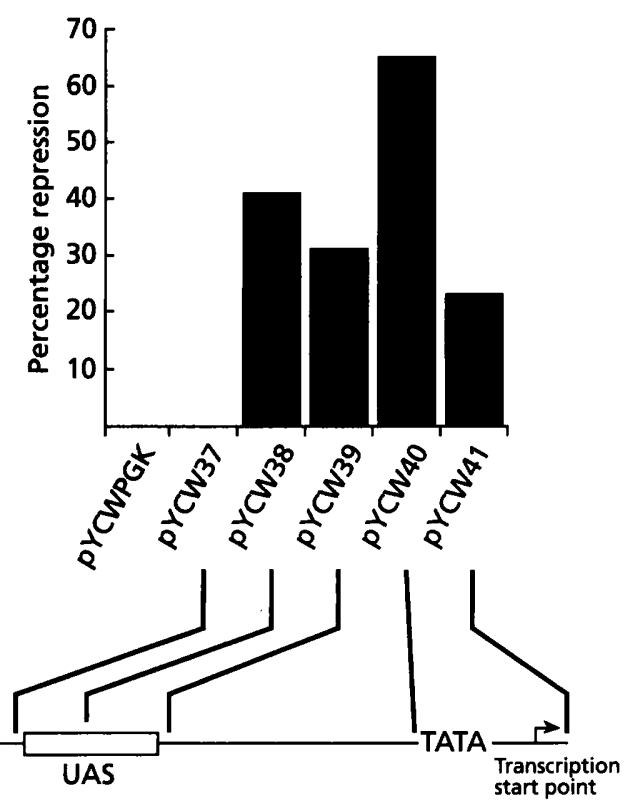

Fig. 4. Repression of PGK promoters containing 434 operators by the 434 repressor. pYCWPGK is the construct containing the wild-type PGK promoter. pYCW37 contains an operator $5^{\prime}$ of the UAS. pYCW38 contains an operator $5^{\prime}$ of the RAP1-binding site within the UAS. pYCW39 contains an operator $3^{\prime}$ of the CTICC boxes within the UAS. pYCW40 contains an operator $5^{\prime}$ of the TATA box. pYCW41 contains an operator $3^{\prime}$ of the transcription start-point.

The PGK promoter contains two functional TATA boxes, at positions -152 and -113 , although the one at position -152 is preferred (Rathjen \& Mellor, 1990). It also contains a CT-rich region close to the transcription start-point which is common to other yeast genes, although this has been shown by deletion analysis not to be required for efficient transcription (Rathjen \& Mellor, 1990). A short sequence of 7 bases, ACAGATC, appears to influence the initiation-site, being sufficient for the discrete determination of the latter when located at the correct distance from the TATA box (Rathjen \& Mellor, 1990). In this region two operators have been positioned, one inserted immediately $5^{\prime}$ to the TATA box at -152 and one by replacement of DNA immediately downstream of the transcription-initiation point. It was hoped that neither insertion of the operator, locating the operator upstream of the TATA box, nor replacement of sequences near the initiation point with operator sequences would alter the transcription-startpoint.

Measurement of $\beta$-galactosidase activities expressed from the reporter constructs containing these altered promoters, in the absence of the 434 repressor, revealed expression at levels very similar to those obtained with the wild-type promoter. In the presence of the 434 repressor, the operator positioned closed to the TATA box gave the greatest repression in this study, reducing expression by $65 \%$ (Fig. 4, Table 1). This repression is likely to be due to steric interference with the formation of the TFIID complex at the TATA box, with consequent inhibition of the initiation of transcription. 
Table 1. Repression of $\beta$-galactosidase gene expression from PGK promoters containing 434 operators

\begin{tabular}{|lllr|}
\hline $\begin{array}{l}\text { Parent } \\
\text { plasmid* }\end{array}$ & Location of operator & $\begin{array}{l}\text { Reporter } \\
\text { plasmid }\end{array}$ & $\begin{array}{r}\text { Percentage } \\
\text { repressiont }\end{array}$ \\
\hline pYCWPGK & Wild-type promoter & pYCWWT & $0(3 \cdot 0)$ \\
pYCW3 & 5' of ABF1 binding site & pYCW37 & $0(3 \cdot 3)$ \\
pYCW4 & 5' of RAP1 binding site & pYCW38 & $41(2 \cdot 8)$ \\
pYCW5 & 3' of last CTTCC box & pYCW39 & $31(2 \cdot 2)$ \\
pYCW6 & 5' to TATA box & pYCW40 & $65(1 \cdot 8)$ \\
pYCW7 & Downstream of RNA start-point & pYCW41 & $22(9 \cdot 8)$ \\
\hline
\end{tabular}

* Refers to the parent plasmid containing the mutated PGK promoter prior to the introduction of the operator.

† Using Student's $t$-test, repression results for $\mathrm{pYCWWT}$ and $\mathrm{pYCW} 37$ conform to the null hypothesis, that is there is no significant difference between the control and the experimental data. All other repression results show that the control and repressed data are from different populations to better than $95 \%$ certainty. The figures in parentheses represent the standard deviation of the percentage repression, calculated using formulae for the propagation of error.

An operator positioned downstream of the transcriptionstartpoint allowed repression at approximately $22 \%$. This relatively low level is likely to reflect the fact that preinitiated transcription is only moderately impeded by the presence of the 434 repressor bound to its operator. Deuschle et al. (1990) showed that the lac repressor could act as an efficient block to transcript-elongation by RNA polymerase II in mammalian cells. The difference between the findings with the 434 repressor and the lac repressor in this instance are probably due to the differences in the dissociation constants, $K_{\mathrm{D}}$, of the two repressors. The lac repressor has an estimated $K_{\mathrm{D}}$ of $10^{-13} \mathrm{M}$ (Riggs et al., 1970 ), compared with a $K_{\mathrm{D}}$ of $10^{-9} \mathrm{M}$ for the 434 repressor bound to the operator used in this study (Koudelka et al., 1988): thus the lac repressor would be less likely to be displaced by the passage of RNA polymerase II.

The PGK promoter has been shown to be dependent on a UAS for its high activity (Ogden et al., 1986), with only sequences $3^{\prime}$ of position -538 being necessary for efficient transcription (Stanway et al., 1989). This UAS has been studied in detail and the transcription factors which bind it well characterized (Stanway et al., 1987, 1989; Chambers et al., 1988, 1989, 1990). Binding sites for the transcription factors RAP1 and ABF1 have been located. In addition, the UAS contains three copies of the pentamer sequence CTTCC which are important for high levels of transcription, but the associated transcription factors have not yet been identified.

Since the arrangement of the UAS is important for the high levels of expression seen from this promoter, the 434 operators were introduced at sites least likely to disrupt the function of the promoter, but where the binding of the 434 repressor would be likely to inhibit the protein-DNA interactions between yeast transcription factors and the UAS. One operator was placed immediately $5^{\prime}$ of the ABF1-binding site, a second immediately downstream of the $3^{\prime}$ CTTCC box and a third introduced as a replacement of DNA between the ABF1-binding site and the RAP1binding site such that the binding of a repressor would be likely to interfere with the binding of RAP1.

The operator $5^{\prime}$ of the UAS (pYCW37) did not yield detectable repression. This observation is consistent with the finding that deletion of the ABF1-binding site has little effect on the rate of transcription from the $P G K$ promoter (Stanway et al., 1987), though this element is essential for correct initiation in the absence of the RAP1 binding site (Stanway et al., 1989).

The operators positioned adjacent to the RAP1-binding site (PYCW38) or immediately downstream of the CTTCC boxes ( $\mathrm{YYCW} 39$ ) within the UAS give similar levels of repression in the presence of the 434 repressor: $41 \%$ for $\mathrm{pYCW} 38$ and $31 \%$ for $\mathrm{pYCW} 39$. In addition to direct competition for access to the UAS between the 434 repressor and the transcription factors, it is also possible that, by bending the operator DNA on binding, the 434 repressor alters the conformation of the UAS sufficiently to alter binding of the transcription factors.

The results presented here for the repression of a $P G K$ promoter- $\beta$-galactosidase fusion reporter system in yeast by the 434 repressor are remarkably similar to those obtained by Smith et al. (1988) for repression of a thymidine kinase promoter-chloramphenicol acetyltransferase reporter system by the $E$. coli lex $A$ repressor in mammalian cells. The lex $A$ repressor was able to produce repression levels between 16 and $61 \%$ when single operators were introduced into the promoter of the reporter construct. The best repression of $61 \%$ was seen when the operator was located $5 \mathrm{bp}$ upstream of the TATA box, an almost identical position to that of the 434 operator in $\mathrm{PYCW} 40$ which produced a very similar level of repression $(65 \%)$. The 434 and the lex $A$ repressors also have similar dissociation constants of $10^{-9} \mathrm{M}$ (Koudelka et al., 1988; Brent \& Ptashne, 1984). However, in yeast the 
Table 2. 434 operator sites within the S. cerevisiae DNA sequences present in the EMBL database

Searches were carried out using the GCG program Findpatterns (Devereux et al., 1984) with the pattern

$\operatorname{ACAA}(\mathrm{G} / \mathrm{A} / \mathrm{T})(\mathrm{A} / \mathrm{T})(\mathrm{A} / \mathrm{T})(\mathrm{A} / \mathrm{T})(\mathrm{A} / \mathrm{T})(\mathrm{A} / \mathrm{T} / \mathrm{C}) \mathrm{TTGT}$. This pattern is based on the influence of the central bases on the affinity of the operator for the 434 repressor. The position of the operator-like sequence within the database entry is indicated, together with the sequence of the operator and flanking DNA.

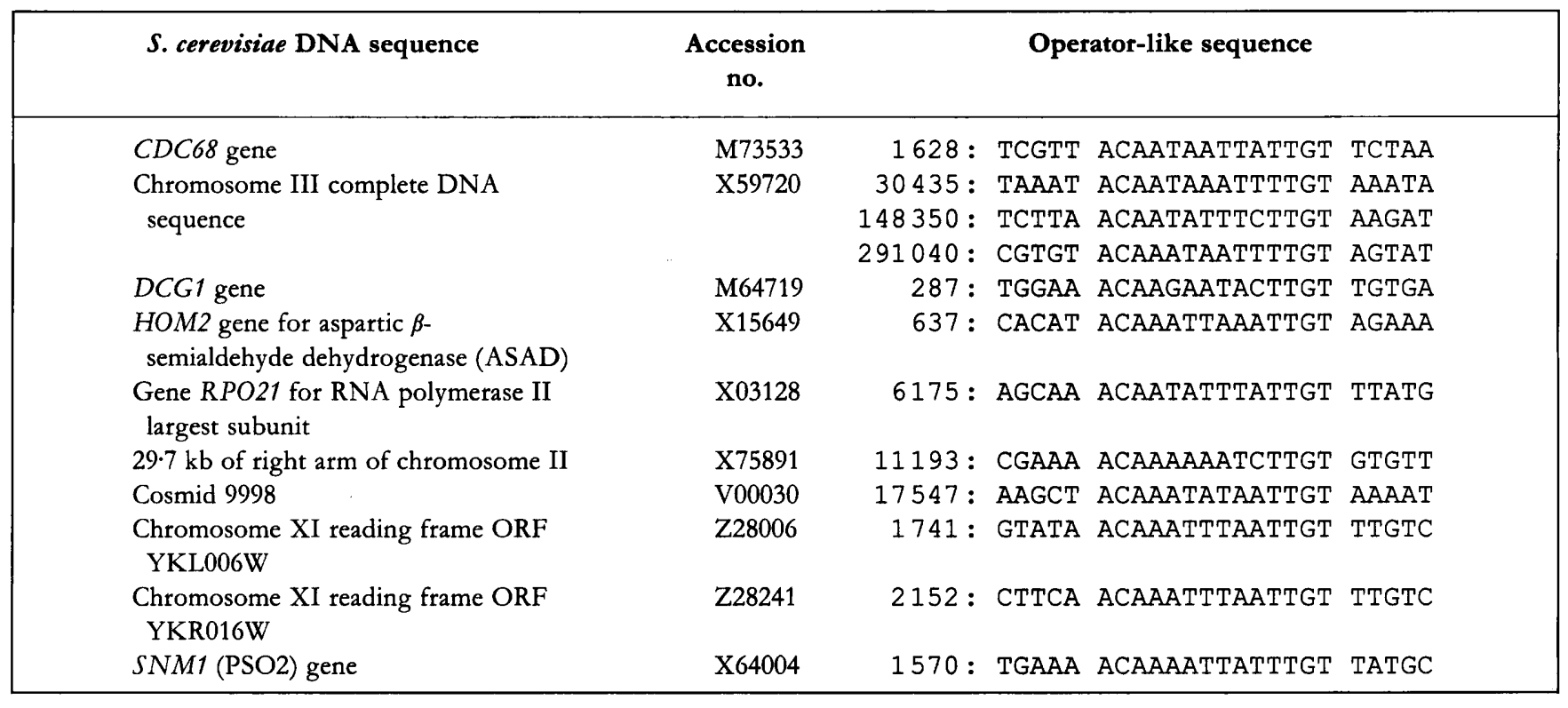

lex $A$ repressor has been used to repress expression from a $G A L 1$ promoter containing lex $A$ operators (Brent \& Ptashne, 1984). Here the level of repression was considerably higher than either the 434 repressor in this study or the lex $A$ study of Smith et al. (1988).

Other bacterial repressors have also produced higher levels of repression in eukaryotic cells than the 434 repressor in this study. In yeast the tet repressor was able to repress RNA polymerase III-based transcription of a tRNA gene by up to 50-fold (Dingermann et al., 1992), substantially higher repression than achieved with any other bacterial repressor used in yeast. In plant cells, repression levels of 10-fold have been reported for the tet repressor in transient assay in tobacco protoplasts (Gatz \& Quail, 1988) and in stably transformed lines (Gatz et al., 1991). Repression could be increased to 80 -fold in the stably transformed lines by the use of tandem operators. Using the lac repressor in tobacco cells, repression levels of up to 10-fold were observed by transient assay and in stably transformed lines (Wilde et al., 1992). In mammalian cell culture, repression levels of between 8- and 12.5-fold have been reported for single operator-insertions and up to 50-fold for double operator-insertions $(\mathrm{Hu} \&$ Davidson, 1987; Brown et al., 1987). As the lac repressor has a much lower $K_{\mathrm{D}}$ than other bacterial repressors, higher repression levels might have been expected. The reasons for large variations in repression levels are unclear, but may reflect differing sensitivities of eukaryotic promoters to repression, as has been observed with bacterial promoters (Lanzer \& Bujard, 1988). Direct comparisons of the efficiency of bacterial repressors in eukaryotic cells can only be made if identical hosts, promoters and positions of operator insertion are used for the analysis.

\section{Growth-inhibitory effect of the $434^{p 22}$ repressor in yeast}

Attempts to transform yeast with the $2 \mu \mathrm{m}$ plasmid ( $\mathrm{pYCW} 28$ ) or the integrating plasmids ( $\mathrm{pYCW} 20 \mathrm{~A}$ or $\mathrm{B}$ ) designed to express the $434^{\mathrm{P} 22}$ repressor were consistently unsuccessful. Control plasmids similar to the expression plasmids except for lacking the $434^{\mathrm{P} 22}$ expression cassette transformed S. cerevisiae S150 2B at high frequency under identical conditions. This information implicates the $434^{\mathbf{P 2 2}}$ repressor as an inhibitor of yeast cell growth.

To investigate this phenomenon further, the plasmid pYCW42 (Fig. 3c) was constructed to allow galactoseinducible expression of the $434^{\mathrm{P22}}$ repressor in yeast. $S$. cerevisiae $\mathrm{S} 150-2 \mathrm{~B}$ was transformed with the vectors pYCW42 and pBM150 (Johnston \& Davis, 1984) and the transformation mixtures divided into two: one half was plated onto semi-defined minimal medium containing glucose, leucine, tryptophan and histidine and the other half onto identical medium containing galactose in place of the glucose. The plates were incubated at $30^{\circ} \mathrm{C}$ until colonies appeared. Both plasmids produced highefficiency transformation, as judged by the number of colonies appearing on the glucose plates. The control plasmid $\mathrm{pBM} 150$ also produced a large number of transformants on the galactose plates. However, the plasmid pYCW42 failed to produce colonies on the galactose plates. When colonies from the glucose plates were streaked onto galactose plates, those containing the plasmid pBM150 were able to grow, whereas cells 
Table 3. P22 operator sites found in the $S$. cerevisiae DNA sequences present in the EMBL database

Searches were carried out using the GCG program Findpatterns (Devereux et al., 1984) with the pattern ANTNAA(G/A/T)(A/T)(A/T) $(\mathrm{A} / \mathrm{T})(\mathrm{A} / \mathrm{T})(\mathrm{A} / \mathrm{T} / \mathrm{C}) \mathrm{TTNANT}$, where $\mathrm{N}=\mathrm{G}, \mathrm{A}, \mathrm{T}$ or $\mathrm{C}$. This pattern is based on the influence of the central bases on the affinity of the operator for the P22 repressor. The $434^{\mathrm{P} 22}$ repressor is identical to the 434 repressor apart from four amino acids within the DNAbinding helix, which have been altered to switch the DNA-binding specificity to that of the P22 repressor. The position of each operator-like sequence within the database entry is indicated, together with the sequence of the operator and flanking DNA.

\begin{tabular}{|c|c|c|c|c|c|}
\hline \multirow{2}{*}{$\begin{array}{l}\text { S. cerevisiae DNA sequence } \\
\text { Argininosuccinate lyase }(A R G 4) \text { gene }\end{array}$} & \multirow{2}{*}{$\begin{array}{c}\begin{array}{c}\text { Sequence } \\
\text { no. }\end{array} \\
\text { K01813 }\end{array}$} & \multicolumn{4}{|c|}{ Operator-like sequence } \\
\hline & & 199: & CAGGC & АТTТААТTТTТСТTТАСТ & CTTCC \\
\hline Nuclear $A T P 2$ gene encoding mitochondrial $\mathrm{F}_{1}$ ATPase & M12082 & $1817:$ & TATTC & ACTAAAAAAAAATTTATT & CTATA \\
\hline \multirow[t]{2}{*}{$A T R 1$ gene conferring aminotriazole resistance } & M20319 & $2853:$ & CAAAA & AATTAAATTAAATTAAAT & TAATA \\
\hline & & $2864:$ & ATTAA & ATTAAATTAATATTAAAT & GTCAT \\
\hline Gene for aspartyl-tRNA synthase & $\mathrm{X} 06665$ & $323:$ & GAAGA & AATGAAAAATTATTTAAT & GTCAT \\
\hline$R I M, M S I 1, P G I$, and ribosomal protein L21 genes & Z21487 & $22050:$ & CAGAC & AGTAAAATTTTTTTCATT & CATTA \\
\hline Chromosome III complete DNA sequence & $\mathrm{X} 59720$ & 100789: & GAGAA & ACTGAAATTTTATTGAGT & GTTTT \\
\hline $\begin{array}{l}\text { Kinesin-related protein }(C I N 8) \text { gene and protease B (PR } 81) \\
3^{\prime} \text { end }\end{array}$ & M90522 & $81:$ & GATAA & ATTGAATATTATTTAATT & CTTCA \\
\hline \multirow[t]{2}{*}{ Chromosome segregation (CSE1) gene } & L14838 & $3490:$ & AAGAA & AATCAAGTAAAATTAAAT & CAATT \\
\hline & & $2203:$ & TTACT & ATTGAAAAAATTTTGACT & ATTAG \\
\hline$E M P 70$ gene for $\mathrm{p} 24 \mathrm{a}$ protein & $\mathrm{X} 67316$ & $946:$ & ATGAT & AATGAAGTTTATTTTACT & TATTC \\
\hline ENO1 gene for enolase 1 & D14474 & $622:$ & ATATT & AATCAAATTTATTTTACT & TCTTT \\
\hline ESP1 gene & L07289 & $1353:$ & GACCT & AATAAAATATATTTAAAT & TCATT \\
\hline Genes for histone $\mathrm{H} 3$ and $\mathrm{H} 4$ (copy-I genes from PMS191) & X00724 & 1714: & AGGGT & АTTTAАTTTAАTTTTAAT & TGGGT \\
\hline Genes HSS1, NPL4 and HSP & X72224 & $358:$ & AATTC & AATTAATTTAACTTCAGT & TTCAA \\
\hline Chromosomes IX and $\mathrm{X}$ telomere, $\mathrm{X}-\mathrm{Y}^{\prime}$ junction & M63935 & $670:$ & TTATT & ATTCAAAATATTTTAAAT & ACAAA \\
\hline SceL12eI $A$ gene encoding L12eIA protein & M26505 & $786:$ & TTGTG & ATTTAAAAATAATTAATT & ACTGT \\
\hline MEF1 gene for mitochondrial elongation factor $G$ & $\mathrm{X} 58378$ & $2629:$ & ACACT & AATTAAGTAAATTTAAAT & AAAAA \\
\hline Nuclear class I differentially regulated mRNA clone mit78 & M15163 & $80:$ & TTGTG & ATTTAAAAATAATTAATT & ACTGT \\
\hline Gene for mitochondrial ribosomal protein L6 & X69480 & $2744:$ & ATATC & AGTGAAATTTTTTTCACT & GGAAG \\
\hline NME1 gene encoding RNA component of RNase MRP & Z14231 & $318:$ & AATGG & AGTAAAATTTTTTTTACT & CAGTA \\
\hline PHO81 gene & D13228 & $5067:$ & ATTTG & ATTAAATTTATCTTTAAT & TCTTA \\
\hline Protease $\mathrm{B}(P R B 1)$ gene & M18097 & $3836:$ & GATAA & ATTGAATATTATTTAATT & CTTCA \\
\hline PSE-1 gene & Z11538 & 216: & CAGAA & ACTGAAAAATTTTTCATT & TTCTA \\
\hline Protein-tyrosine phosphatase gene & M82872 & 19: & ACATC & ACTCAAAATTAATTGATT & TGCCT \\
\hline PUP1 gene & X61189 & $306:$ & ACTAT & ACTAAAATATACTTAAGT & TCTAT \\
\hline $\mathrm{R} A D H$ gene for putative helicase & $\mathrm{X} 15665$ & $4521:$ & ATAGG & AGTTAATTTTATTTTACT & GGTAG \\
\hline REC114 gene & Z14315 & $83:$ & TAGGA & AATAAAATAAAATTCAGT & TTACC \\
\hline Tyrosine phosphatase $P T P 2$ gene & M38723 & $3157:$ & AGGCA & AATCAATTAATTTTGAGT & GATGT \\
\hline$R E V 1$ gene required for normal induction of mutation & M22222 & $3433:$ & TGGAC & AATTAAATAAAATTAAGT & AAAAA \\
\hline Ribosomal protein L45 gene & J03761 & $870:$ & TTGTG & АTTTAAAAATAATTAATT & ACTGT \\
\hline RPC53 gene for RNA polymerase $C$ subunit 4 & $\mathrm{X} 63501$ & $543:$ & TCATT & АTTGAATTTTTTTTCATT & GCAGA \\
\hline$S D H 1$ gene for L-serine dehydratase & X52657 & $2609:$ & AGAGT & AGTAAAGAAAATTTTATT & TACAT \\
\hline tRNA-Glu(3) gene and flanking regions (CYH82) & X08049 & $1054:$ & GATAT & АTТTAАТАTTTTTTTAАT & TTGAC \\
\hline \multirow[t]{2}{*}{ Vanadate-resistance protein $(V A N 1)$ gene } & M33957 & 1980: & TATTA & ATTTAATTTAATTTAATT & TTTTG \\
\hline & & $1969:$ & ATGAC & АТTTAATATTAАTTTAAT & TTAAT \\
\hline \multirow[t]{2}{*}{ Casein kinase I (YCK2) gene } & M74453 & 278: & TGAGT & AATGAAAAATTTTTAATT & TTTTC \\
\hline & & $2407:$ & СТАТT & ATTAAAAAAATATTAAGT & ACTTT \\
\hline Chromosome III complete DNA sequence & $\mathrm{X} 59720$ & $100789:$ & GAGAA & ACTGAAATTTTATTGAGT & GTTTT \\
\hline$S M Y 2$ gene & X74437 & $2543:$ & TTGAA & ACTGAAGTTAAATTAATT & GAATT \\
\hline Genes for histone $\mathrm{H} 2 \mathrm{~A}$ and $\mathrm{H} 2 \mathrm{~B}$, trehalase, and hexapren 388 & Z26494 & $6948:$ & TATTT & ATTTAATTATTATTAAGT & AAAAA \\
\hline Sec66p (SEC66) gene & U00797 & $550:$ & TTGAA & ACTGAAGTTAAATTAATT & GAATT \\
\hline CKI1 mRNA for casein kinase- 1 & $\mathrm{X} 60326$ & $1890:$ & CTATT & ATTAAAAAAATATTAAGT & ACTTT \\
\hline $\begin{array}{l}\text { Chromosome XI (28.6 kb) DNA for F206/YKL331, } \\
\text { B969/YKL3 }\end{array}$ & $\mathrm{X} 75781$ & $9685:$ & TCAAA & AАTCAATAATAATTAATT & TAATA \\
\hline Genes HSS1, NPL4 and HSP & X72224 & $358:$ & AATTC & AATTAATTTAACTTCAGT & TTCAA \\
\hline Gene for rab geranylgeranyl transferase & D26441 & $92:$ & TAAAC & ATTTAAGTTTAATTTATT & ACTGT \\
\hline FET3 gene & L25090 & $2457:$ & TСTCT & AGTAAAAAATAATTTACT & СТАTT \\
\hline Chromosome X left telomere $40 \cdot 1 \mathrm{~kb}$ DNA fragment & Z34098 & $4303:$ & TTTGT & ATTTAAAATATTTTGAAT & AATAA \\
\hline
\end{tabular}


Table 3. (cont.)

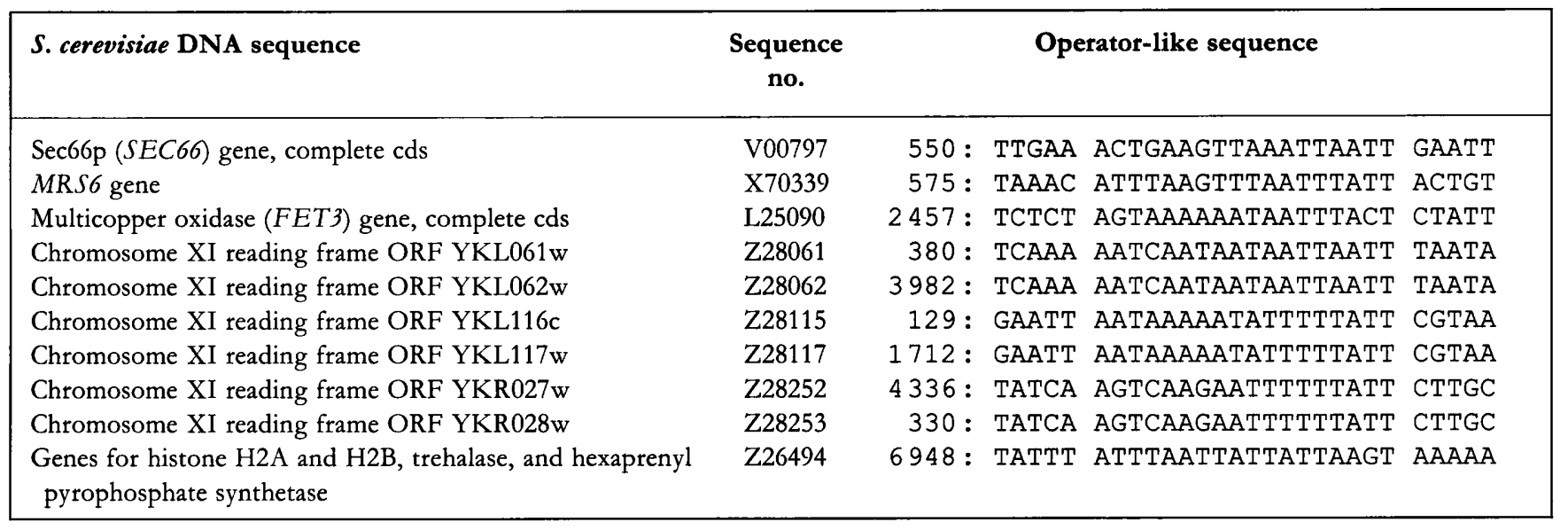

containing the plasmid pYCW42 were unable to grow on the galactose media. These observations support the notion that the $434^{\mathrm{P} 22}$ repressor is inhibitory to the growth of the yeast: cells having the $434^{\mathrm{P22}}$ repressor gene under the control of the GAL1 promoter have a galactose-sensitive phenotype.

Examination of yeast sequences in the EMBL database for both 434 and P22 operator-like sequences revealed potential repressor-binding sites in yeast genomic DNA (Tables 2 and 3). Despite the identical number of conserved bases used for the search pattern for each operator sequence, there are twelve 434 operator-like sequences compared to 59 for the P22 operator. The conserved bases of the P22 operator are exclusively A/T base-pairs whereas the 434 operator contains two G/C base-pairs. The $S$. cerevisiae genome is approximately $64 \%$ A/T (Strickberger, 1976), which would favour the existence of P22 operators over 434 operators in the ratio of approximately $3: 1$. This suggests that more yeast genes could be repressed by the $434^{\mathrm{P} 22}$ repressor than the wildtype 434 repressor.

The yeast genes containing P22 operator sequences include several encoding essential proteins, including three ribosomal proteins, a subunit of RNA polymerase III, an aminoacyl tRNA synthase and two histone proteins. However, it is impossible to determine at present whether the growth-inhibiting effect of the $434^{\mathbf{P 2 2}}$ repressor is due to repression of a single gene or of two or more of those containing operator-like sequences. Selection and analysis of galactose-resistant derivatives of the galactose-sensitive yeast containing the galactoseinducible $434^{\mathbf{P 2 2}}$ repressor could be informative. Repression studies in yeast using either the $434^{\mathrm{P22}}$ homodimer or the $434 / 434^{\mathrm{P} 22}$ heterodimer have obviously been made impractical by these findings.

\section{ACKNOWLEDGEMENTS}

We are grateful to Chris Hadfield, Peter Meacock, Dave Pioli, Melvyn Hollis, Rob Wilde and Wolfgang Schuch for strains and valuable discussion, to Debbie Langton for oligonucleotides, to ICI Strategic Science Fund for recurrent support, and to SERC and Zeneca Seeds for a CASE Postgraduate Training Award to C.W.

\section{REFERENCES}

Aggarwal, A. K., Rodgers, D. W., Drotar, M., Ptashne, M. \& Harrison, S. C. (1988). Recognition of a DNA operator by the repressor of phage 434: a view at high resolution. Science 242, 899-907.

Anderson, J. E., Ptashne, M. \& Harrison, S. C. (1985). A phage repressor operator at $7 \AA$ resolution. Nature 316, 596-601.

Anderson, J. E., Ptashne, M. \& Harrison, S. C. (1987). Structure of the repressor-operator complex of bacteriophage 434. Nature 326, 846-852.

Beier, D. R. \& Young, E. T. (1982). Characterisation of a regulatory region upstream of the $A R D 2$ locus of $S$. cerevisiae. Nature 300, 724-728.

Brent, R. \& Ptashne, M. (1984). A bacterial repressor protein or a yeast transcriptional terminator can block upstream activation of a yeast gene. Nature 312, 612-615.

Brown, M., Figge, J., Hansen, U., Wright, C., Jeang, K.-T., Khoury, G., Livingston, D. M. \& Roberts, T. M. (1987). lac repressor can regulate expression from a hybrid SV40 early promoter containing a lac operator in animal cells. Cell 49, 603-612.

Bullock, W. O., Fernandez, J. M. \& Short, J. M. (1987). XL1-blue: a high efficiency plasmid transforming $\operatorname{rec} A$ Escherichia coli strain with beta-galactosidase selection. Biotechniques 5, 376-379.

Chambers, A., Stanway, C., Kingsman, A. J. \& Kingsman, S. M. (1988). The UAS of the yeast PGK gene is composed of multiple functional elements. Nucleic Acids Res 16, 8245-8260.

Chambers, A., Tsang, J. S. H., Stanway, C., Kingsman, A. J. \& Kingsman, S. M. (1989). Transcriptional control of the Saccharomyces cerevisiae PGK gene by RAP1. Mol Cell Biol 9, 5516-5526.

Chambers, A., Stanway, C., Tsang, J. S. H., Henry, Y., Kingsman, A. J. \& Kingsman, S. M. (1990). ARS binding factor 1 binds adjacent to RAP1 at the UASs of the yeast glycolytic genes $P G K$ and PYK1. Nucleic Acids Res 18, 5393-5399.

Derynck, R., Singh, A. \& Goeddel, D. V. (1983). Expression of the human interferon- $\gamma$ cDNA in yeast. Nucleic Acids Res 11, 1819-1837.

Devereaux, J., Haeberli, P. \& Smithies, O. (1984). A comprehensive set of sequence analysis programs for the VAX. Nucleic Acids Res 12, 387-395. 
Deuschle, U., Hipskind, R. A. \& Bujard, H. (1990). RNA polymerase II transcription blocked by Eschericbia coli lac repressor. Science 248, 480-483.

Dingermann, T., Frank-Stoll, U., Werner, H., Wissmann, A., Hillen, W., Jacquet, M. \& Marschalek, R. (1992). RNA polymerase III catalysed transcription can be regulated in Saccharomyces cerevisiae by the bacterial tetracycline repressor-operator system. EMBO J 11, $1487-1492$

Figge, J., Wright, C., Collins, C. J., Roberts, T. J. \& Livingston, D. M. (1988). Stringent regulation of stably integrated chloramphenicol acetyl transferase genes by $E$. coli lac repressor in monkey cells. Cell 52, 713-728.

Gatz, C. \& Quail, P. H. (1988). Tn10-encoded tet repressor can regulate an operator-containing plant promoter. Proc Natl Acad Sci US $A$ 85, 1394-1397.

Gatz, C., Kaiser, A. \& Wendenburg, R. (1991). Regulation of a modified CaMV $35 \mathrm{~S}$ promoter by the Tn10-encoded tet repressor in transgenic tobacco. Mol \& Gen Genet 227, 229-237.

van Gorcom, R. F. M., Punt, P. J., Pouwels, P. H. \& van den Hondel, C. A. M. J. J. (1986). A system for the analysis of expression signals in Aspergillus. Gene 48, 211-217.

Hadfield, C., Cashmore, A. \& Meacock, P. A. (1986). An efficient chloramphenicol resistance marker for Saccharomyces cerevisiae and Escherichia coli. Gene 45, 149-158.

Hadfield, C., Cashmore, A. M. \& Meacock, P. A. (1987). Sequence and expression characteristics of a shuttle chloramphenicol-resistance marker for Saccharomyces cerevisiae and Escherichia coli. Gene 52, 59-70.

Hadfield, C., Jordan, B. E., Mount, R. C., Pretorious, G. H. S. \& Burak, E. (1990). G418 resistance as a dominant marker and reporter for gene expression in Saccharomyces cerevisiae. Curr Genet 18, 303-313.

Hanahan, D. (1983). Studies on transformation of Escherichia coli with plasmids. $J$ Mol Biol 166, 557-580.

Hollis, M., Vakenzuela, D., Pioli, D., Wharton, R. \& Ptashne, M. (1988). A repressor heterodimer binds to a chimeric operator. Proc Natl Acad Sci US A 85, 5834-5838.

Hu, M. C.-T. \& Davidson, N. (1987). The inducible lac operatorrepressor system is functional in mammalian cells. Cell 48, 555-566.

Johnston, M. \& Davis, R. W. (1984). Sequences that regulate the divergent GAL1-GAL10 promoter in Saccharomyces cerevisiae. Mol Cell Biol 4, 1440-1448.

Koudelka, G. B., Harburg, P., Harrison, S. C. \& Ptashne, M. (1988). DNA twisting and affinity of bacteriophage 434 operator for bacteriophage 434 repressor. Proc Natl Acad Sci USA 85, 4633-4637.

Kunkel, T. A., Roberts, J. D. \& Zakour, R. A. (1987). Rapid and efficient site-specific mutagenesis without phenotypic selection. Methods Envymol 154, 367-373.

Lanzer, M. \& Bujard, H. (1988). Promoters largely determine the efficiency of repressor action. Proc Natl Acad Sci USA 85, 8973-8977.

Marsh, L., Erfle, M. \& Wykes, E. J. (1984). The pIC plasmid and phage vectors with versatile cloning sites for recombination selection by insertional inactivation. Gene 32, 481-486.

Miller, J. H. (1972). Experiments in Molecular Genetics, pp. 352-355. Cold Spring Harbor, NY: Cold Spring Harbor Laboratory.
Ogden, J. E., Stanway, C., Kim, S., Mellor, J., Kingsman, A. J. \& Kingsman, S. M. (1986). Efficient expression of the Saccharomyces cerevisiae $P G K$ gene depends on an upstream activation sequence but does not require TATA sequences. Mol Cell Biol 6, 4335-4343.

Orr-Weaver, T. C., Szostak, J. W. \& Rothstein, R. J. (1981). Yeast transformation; a model system for the study of recombination. Proc Natl Acad Sci US A 78, 6354-6358.

Pabo, C. O. \& Sauer, R. T. (1984). Protein-DNA recognition. $A n n u$ Rev Biochem 53, 293-321.

Rathjen, J. \& Mellor, J. (1990). Characterisation of sequences required for RNA initiation from the $P G K$ promotor of Saccharomyces cerevisiae. Nucleic Acids Res 18, 3219-3225.

Riggs, A. D., Suzuki, H. \& Bourgeois, S. (1970). lac repressor-operator interaction. I. Equilibrium studies. $J$ Mol Biol $48,67-83$.

Sambrook, J., Fritsch, E. F. \& Maniatis, T. (1989). Molecular Cloning: a Laboratory Manual. Cold Spring Harbor, NY: Cold Spring Harbor Laboratory.

Sanger, F., Donelson, J. E., Coulson, A. R., Koessel, H. \& Fisher, D. (1974). Determination of a nucleotide sequence in bacteriophage F-1 DNA by primed synthesis with DNA polymerase. $J$ Mol Biol 90, 315-333.

Smith, G. M., Mileham, K. A., Cooke, S. E., Woolston, S. J., George, H. K., Charles, A. D. \& Brammar, W. J. (1988). The Escherichia coli lex $A$ repressor-operator system works in mammalian cells. EMBO J 7, 3975-3982.

Soberon, X., Covarrubias, L. \& Bolivar, F. (1980). Construction and characterisation of new cloning vehicles. 4 . Deletion derivatives of pBR322 and pBR325. Gene 9, 287-305.

Stanway, C., Mellor, J., Ogden, J. E., Kingsman, A. J. \& Kingsman, S. M. (1987). The UAS of the yeast $P G K$ gene contains functionally distinct domains. Nucleic Acids Res 15, 6865-6873.

Stanway, C., Chambers, A., Kingsman, A. J. \& Kingsman, S. M. (1989). Characterisation of the transcriptional potency of subelements of the UAS of the yeast PGK gene in a PGK minipromotor. Nucleic Acids Res 17, 9205-9218.

Strickberger, M. W. (1976). Genetics, p. 54. New York: Collier MacMillan.

Webster, C., Merryweather, A. \& Brammar, W. (1992). Efficient repression by a heteromeric repressor in Eschericbia coli. Mol Microbiol 6, 371-377.

Wharton, R. P. \& Ptashne, M. (1985). A new specificity mutant of 434 repressor that defines an amino acid-base pair contact. Nature 326, 888-891.

Wharton, R. P. \& Ptashne, M. (1987). Changing the binding specificity of a repressor by redesigning an $\alpha$-helix. Nature 316, 601-605.

Wharton, R. P., Brown, E. L. \& Ptashne, M. (1984). Substituting an $\alpha$-helix switches the sequence specific interactions of a repressor. Cell 38, 361-369.

Wilde, R. J., Shufflebottom, D., Cooke, S., Jasinska, I., Merryweather, A., Beri, R., Brammar, W. J., Bevan, M. \& Schuch, W. (1992). Control of gene expression in tobacco cells using a bacterial operator-repressor system. EMBO J 11, 1251-1259.

Received 15 August 1994; revised 18 May 1995; accepted 2 June 1995. 